\title{
CZCIGODNEMU BRATU NASZEMU KAROLOWI KARDYNAEOWI WOJTYLE ARCYBISKUPOWI KRAKOWSKIEMU
}

Sześćset lat, które upłynęły od urodzin Jadwigi, królowej Polski, dają sposobność Biskupom, duchowieństwu i wiernym tego kraju uczczenia pamięci tej niezwykłej niewiasty i otrzymania od niej przykładów dotyczących współczesnego życia.

Zaiste ta Królowa w krótkim dość czasie swego ziemskiego życia wytrwale ćwiczyła się w cnotach, szerzyła i utwierdzała wiarę katolicką, założyła Wydział Teologiczny Krakowski, tworzyła dzieła miłosierdzia i społecznego postępu - że wspomnimy tylko najważniejsze jej dobre czyny. Cześć więc jej bywa oddawana jako Błogosławionej od niepamiętnych czasów; a proces o zatwierdzenie tej czci został rozpoczęty u Stolicy Apostolskiej.

Uroczystości zapowiedziane ku pamięci tej wybranej niewiasty szczęśliwie zbiegają się z czasem, który został wyznaczony do obchodu Roku Swiętego w Kościołach miejscowych i który zbliża się już do Jubileuszu powszechnego mającego być obchodzonym w Rzymie na progach Apostolskich, siedzibie jedności katolickiej.

Życie wewnętrzne, oczyszczenie duszy, pojednanie z Bogiem i z braćmi: oto znane treści wyznaczone dla tych obchodów religijnych, które dotyczą życia osobistego i społecznego. Zaprawdę nie wątpimy, że Ty, Czcigodny Bracie Nasz, który odznaczasz się pasterską troską, oraz inni Arcypasterze Polscy postaracie się, by wasze owczarnie poznały tę ważną sprawę duchową i wprowadziły w życie.

Jadwiga królowa, jak to zaznaczyliśmy, wiele się starała o poszerzenie granic religii katolickiej i ta także sprawa, to znaczy ewangelizacja - jak zawsze, tak i dziś i to szczególniej - leży Kościołowi na sercu; owszem, jak wiadomo, będzie tematem obrad najbliższego zebrania Synodu Biskupów. Nigdy bowiem nie wolno zapominać tych waż- 
nych słów Soboru Watykańskiego II: „W obecnym zaś stanie rzeczy, gdy powstają nowe warunki życia dla ludności, Kościół, sól ziemi i światłość świata (por. Mt 5, 13-14), bardziej jest powołany do zbawiania i odnawiania wszelkiego stworzenia, aby ludzie utworzyli jedną rodzinę oraz jeden lud Boży” (Dekr. „Ad gentes divinitus”, 1). Wszyscy przeto, także i laicy, niech wiedzą, że się ich zachęca do przykładania się jak tylko można najskuteczniej ku tej sprawie prawdziwie apostolskiej.

Nie musimy znów zachęcać do czynów zmierzających w tym kierunku, aby ulżyć nędzy, zadbać o ubogich, aby usuwać niesprawiedliwości: albowiem „trzeba, aby przez to znamię miłości poznawany był Kościół, który radując się $\mathrm{z}$ wysiłków drugich, zachowuje sobie dzieła miłości jako obowiązek i prawo, których nie może się pozbyć" (por. Sob. Wat. II. Dekr. „Apostolicam actuositatem”, 8).

Sam zaś czas święty - Rok Swięty mamy na myśli - wzywa katolików do podwojenia wysiłków, aby zostało wypełnione największe przykazanie Pańskie o miłości.

Życząc wreszcie, aby te święte uroczystości posłużyły do prawdziwego postępu pobożności, Tobie, Czcigodny Bracie, innym Biskupom Polski, Kapłanom, Zakonnikom i Wiernym, którzy w nich będą brać udział, z największą życzliwością udzielamy Błogosławieństwa Apostolskiego, jako zadatku mocy z wysoka i pociechy oraz wyrazu Naszej miłości.

Z Siedziby Watykańskiej, dnia 10 maja roku 1974, jedenastego Naszego Pontyfikatu.

Papież Paweł VI. 